\title{
Effect of Bay Leaf Drink (Syzygium polyanthum) and Soursop Juice (Annona Muricata) on Uric Acid Levels in Patients with Gout
}

\author{
S Asmira ${ }^{1}$, P A Arza ${ }^{2}$, Hamizah $^{3}$ \\ Perintis Institute of Health Sciences, Padang, Indonesia ${ }^{1}$ \\ Alumni from Perintis Institute of Health Sciences, Padang, Indonesia ${ }^{2,3}$ \\ $\left\{\right.$ sepni.asmira@gmail.com $\left.{ }^{1}\right\}$
}

\begin{abstract}
High levels of uric acid, one of the body's waste products, can be a sign of gout or kidney stones, bay leaf drink (Syzygium polyanthum) and soursop juice (Annona muricata) may have the beneficial effect on reducing uric acid levels. The aim of this study was to determine the impact of bay leaf drink (Syzygium polyanthum) and soursop juice (Annona muricata) on uric acid levels. The intervention of bay leaf drink and soursop juice was performed for 28 days and 17 subjects selected purposively and divided into two groups, one group consumed bay leaf drink (group A) and another group consumed soursop juice(Group B). Bay leaf drink and soursop juice were served in drink form as much as $200 \mathrm{ml}$. Significant improvement was identified in uric acid levels of subjects after the intervention $(\mathrm{p}<0.05)$. Decreased uric acid levels in group A and group B $(8.7647 \pm 0.948 \mathrm{mg} / \mathrm{dl}$ to $8.317 \pm 8.1 \mathrm{mg} / \mathrm{dl} ; 7,47 \pm 0.987 \mathrm{mg} / \mathrm{dl}$ to $5.41 \pm 1.35 \mathrm{mg} / \mathrm{dl}$, respectively).
\end{abstract}

Keywords: Bay leaf drink, soursop juice, uric acid levels.

\section{Introduction}

High levels of uric acid, one of the body's waste products, can be a sign of gout or kidney stones. Maintaining too low Serum Uric Acid levels is essential because uric acid is thought to be neuroprotective[1] and some studies have reported an increased risk of several neurodegenerative diseases such as Parkinson's disease[2] or amyotrophic lateral sclerosis with a low serum uric acid level[3].

Uric acid is a metabolic end product of purine compounds which are then excreted through urine, feces, and sweat. Uric acid levels in men are naturally higher than women because women have the hormone estrogen which helped the removal of uric acid through urine. Uric acid levels men tend to increase with increasing age. In women, the increase was started since the menopause. Normal levels of uric acid in women is 2.4 to $6.0 \mathrm{mg} / \mathrm{dL}$ and men 3.0 to $7.0 \mathrm{mg} /$ $\mathrm{dL}$. If it exceeds this value, then someone categorized as having hyperuricemia. Hyperuricemia is an increase in levels of uric acid in the blood exceeds normal limits. The incidence of gout is increased in a state of high uric acid more than $9.0 \mathrm{mg} / \mathrm{dL}$ [4].

One alternative in reducing levels of uric acid that has been studied is to consume bay leaf drink (Syzygiumpolyanthum).In a previous study show that consumed bay leaf drink $0.36 \mathrm{~g} /$ 
$\mathrm{kg}$ had the effect of decreasing uric acid levels [5]. Also base on the research Sriningsih (2008) indicates doses of bay leaves $20 \mathrm{mg} / 200$ grams of Body weight can lower blood uric acid levels.

Beside bay leaf drink, soursop juice also has an important role in reducing uric acid level. Base on the result of Rahman et al. [6] research, found that a significant effect of fruit soursop to decrease uric acid levels in male, white mice hyperuricemia.

\section{Methods}

This study uses a pre post-test with control, which is a design that carries out the treatment in two or more groups were observed before and after implementation. Measurements were performed before administration(pretest)and after being given (posttest).

Sampling in this study conducted by purposive sampling determination among the samples according to the desired population of researchers based on a particular consideration in accordance with the criteria, such as inclusion and exclusion criteria.

In this study, researchers used a sample of 17 samples given $200 \mathrm{ml}$ bay leaf drink, and 17 subjects are given $200 \mathrm{ml}$ of soursop juice. The total number of samples is 34 (thirty-four) patients with uric acid in the district of Kuantan Singingi Riau Province, Indonesia. This intervention was conducted in seven days.

\section{Results and Discussion}

\subsection{Uric acid levels before and after consumed bay leaf drink and soursop juice in patients with uric acid}

Measurement of uric acid levels before and after consumed bay leaf drink and soursop juice in patients with gout presented in the form of table 3.1. In Table 3.1 it can be seen that in the intervention group before consumed bay leaf drink, uric acid levels low most $7.3 \mathrm{mg} / \mathrm{dL}$ and a maximum of $10.60 \mathrm{mg} / \mathrm{dL}$ with an average level of uric acid $8.7647 \mathrm{mg} / \mathrm{dL}$.

Statistics analysis results showed a significant decrease in uric acid levels of group A and group $\mathrm{B}(\mathrm{P}<0.05)$. a greater reduction in uric acid levels was observed in group A compared with the group B. Decreased uric acid levels in group A and group B $(8.7647 \pm 0.948 \mathrm{mg} / \mathrm{dl}$ to $8.317 \pm 8.1 \mathrm{mg} / \mathrm{dl} ; 7,47 \pm 0.987 \mathrm{mg} / \mathrm{dl}$ to $5.41 \pm 1.35 \mathrm{mg} / \mathrm{dl}$, respectively).

This is consistent with the theory Dalimartha [7] revealed that the bay leaf drink could lower uric acid levels in the blood. The overall decline in levels of uric acid in the respondents although there are respondents who are still suffering from gout or uric acid levels are still above normal respondents. This study also follows previous research by Darussalam [5] on the role of bay leaf drink lowering uric acid levels in patients with gout. A significant difference before and after the administration of bay leaves. The research result Darussalam[5] found a decrease in uric acid levels on average 0.4. In this study also saw a reduction in mean uric acid levels - a 0.4 average. According to the existing theory, bay leaf contain chemicals that include flavonoids, tannins, polyphenols, alkaloids and essential oils that can multiply the production of urine so that it can lower uric acid levels in the blood[8].

Flavonoids contained in the leaves can bind compound enzyme Xanthin oxidase that can reduce the formation of Xanthin to form uric acid. Flavonoids structure having a double bond can efficiently bind the compound enzyme, Xanthin oxidase resulting in the creation of uric acid metabolism can be controlled. This affects the levels of uric acid in the blood that can gradually - gradually decreased. Additionally flavonoid compound is a diuretic so that it can lower uric 
acid levels[8]. Flavonoids also act blood circulation throughout the body and prevent blockages in blood vessels, contains anti-inflammatory (anti-inflammatory), functions as an antioxidant and helps reduce pain(analgesic)[9]. Tannins, polyphenols, such as flavonoids have diuretic properties that also help remove uric acid in the urine[10].

Table 3.1 shows that the intervention group before being given a soursop juice obtained levels of uric acid the least $6.0 \mathrm{mg} / \mathrm{dL}$ and a maximum of 9:40 mg / dL with average uric acid levels after administration of soursop juice for seven days is $7.47 \mathrm{mg} / \mathrm{dL}$. The result of this research showed that all respondents in this study before the given intervention are the provision of soursop juice gout patients as many as seventeen respondents (100\%). Researchers took samples of the respondents all gout sufferers because researchers will compare the effectiveness before and after administration of soursop juice in patients with gout.

Increased production of uric acid occurs due to the increased speed of purine biosynthesis of amino acids to form the nucleus of the cell DNA and RNA. Uric acid production is aided by the enzyme xanthine oxidase(xanthine oxidase), with side effects that produce free radicals superoxidase [11].

Based on Table 3.1 it can be seen that in the intervention group after being given water decoction of leaves obtained uric acid levels in the lowest $7.1 \mathrm{mg} / \mathrm{dL}$ and a maximum of 10.3 $\mathrm{mg} / \mathrm{dL}$ with an average level of uric acid $8317 \mathrm{mg} / \mathrm{dL}$.

Table 3.1 Uric acid levels before and after the water decoction of leaves and soursop juice in patients with uric acid

\begin{tabular}{ccccccc}
\hline \multirow{2}{*}{ Group } & & \multicolumn{5}{c}{ Levels of Uric Acid (mg / dL) } \\
\cline { 3 - 7 } & Treatment & Mean & Median & SD & Min & Max \\
\hline \multirow{2}{*}{$\begin{array}{c}\text { Bay leaf drink } \\
\text { (A) }\end{array}$} & pretest & 8.7647 & 8.60 & 0948 & $7: 30$ & 10.60 \\
\cline { 2 - 7 } & posttest & 8317 & 8.1 & 0.8748 & 7.1 & 10.3 \\
\hline $\begin{array}{c}\text { Soursop Juice } \\
\text { (B) }\end{array}$ & pretest & $7: 47$ & 7.5 & 0.987 & 6.0 & $9: 40$ \\
\cline { 2 - 7 } & posttest & $5: 41$ & 5.2 & $1: 35$ & 3.60 & 7.80 \\
\hline
\end{tabular}

In Table 3.1 it can be seen that in the intervention group after being given soursop juice obtained levels of uric acid the least $3.6 \mathrm{mg} / \mathrm{dL}$ and a maximum of $7.8 \mathrm{mg} / \mathrm{dL}$ with average uric acid levels after administration soursop juice for seven days is $5.41 \mathrm{mg} / \mathrm{dL}$, Based on the results of research in the intervention group was given after soursop juice, most respondents did not suffer from the uric acid by 11 respondents $(64.7 \%)$, and as many as six respondents $(35.5 \%)$ is still suffering from gout. Uric acid levels are lowest is $3.6 \mathrm{mg} / \mathrm{dL}$ and a maximum of $7.8 \mathrm{mg}$ / dL. Average levels of uric acid after being given a bay leaf boiled water for seven days for all respondents was $5.4 \mathrm{mg} / \mathrm{dL}$. It shows that there is a definite response to the soursop in lowering uric acid levels in patients with gout. Indriani [12] states there is the effect of soursop juice to decrease uric acid levels in gout patients ( $p$-value of $0.002<0.05$ ). Average levels - an average reduction of uric acid after being given soursop juice is 2.10 ; this shows the results of the study by Indriani [12] together with a study that researchers do is 2:04.

The effectiveness of providing soursop juice was triggered by the amount of vitamin $\mathrm{C}$ in the soursop fruit is an antioxidant that is effective in the reduction of uric acid. Vitamin $\mathrm{C}$ can increase the excretion of uric acid in the urine. According to Handayani [13] Vitamin C content contained in soursop fruit serves as an antioxidant and can inhibit production of the enzyme xanthine oxidase. Therefore soursop juice can inhibit the formation of uric acid in the body. Soursop fruit also contains flavonoid compounds that inhibit the production of the enzyme xanthine oxidase. 
Vitamin $\mathrm{C}$ in soursop juice is readily soluble in water so quickly absorbed by the body. Vitamins can increase urination and expenditure electrolyte through its influence on the glomerular filtration rate (GFR) in the Bowman's capsule. Vitamin $\mathrm{C}$ acts like potassium, which absorbs liquid electrolyte ions such as sodium in the blood to get to the extracellular entering the renal tubules. Glomerular Filtration Rate (GFR) is high due to the antioxidant activity of vitamin $\mathrm{C}$ causes proximal kidney tubule as much as $65 \%$, and as much as $25 \%$ of the loop of Henle can release products of uric acid from the body quickly. Vitamin $\mathrm{C}$ in soursop juice is readily soluble in water so easily absorbed by the body. Vitamins can increase urination and expenditure electrolyte through its influence on the glomerular filtration rate (GFR) in the Bowman's capsule. Vitamin $\mathrm{C}$ acts like potassium, which absorbs liquid electrolyte ions such as sodium in the blood to get to the extracellular entering the renal tubules. Glomerular Filtration Rate (GFR) is high due to the antioxidant activity of vitamin $\mathrm{C}$ causes proximal kidney tubule as much as $65 \%$, and as much as $25 \%$ of the loop of Henle can release products of uric acid from the body quickly.

\subsection{Effectiveness difference bay leaf drink and Soursop Juice In Lowering Uric Acid Levels In Patients with Uric Acid}

Results of data analysis showed a significant difference in the provision of boiling water and juice soursop leaves in lowering uric acid levels in patients with gout. Giving poorer soursop fruit juice is more effective in reducing uric acid levels compared to the provision of bay leaves boiled water. The effectiveness of providing the soursop fruit juices triggered by the amount of vitamin $\mathrm{C}$ in soursop fruit is an antioxidant that is effective in decreasing uric acid than boiled water bay leaves. Vitamin C can increase the excretion of uric acid in the urine. A 2009 study showed that men who took vitamin $\mathrm{C}$ are more than $1,500 \mathrm{mg}$ per day have a uric acid level lower. If the risk of uric acid, which is $45 \%$ less than those who consumed vitamin $\mathrm{C}$ less than $250 \mathrm{mg}$ per day.

According to Handayani [13] the effectiveness of vitamin $C$ in lowering uric acid levels is because vitamin $\mathrm{C}$ is water-soluble so quickly absorbed by the body compared to the levels of flavonoids contained in the leaves. Flavonoids are one of the antioxidants that also serves in lowering uric acid levels, but the provision of boiling water leaves less effective in reducing uric acid levels compared to the administration of juice soursop fruit that contains vitamin $\mathrm{C}$ which is more soluble in water that is quickly absorbed by the body than flavonoid compounds contained in the leaves.

\section{Conclusion}

Soursop juice is more effective in reducing levels of uric acid levels with the average reduction of uric acid 2.0 compared to bay leaf drink water with average levels reduction of uric acid 0:40 in patients with gout.

\section{References}

[1] J. S. A. M. Reijnders, U. Ehrt, R. Lousberg, D. Aarsland, and A. F. G. Leentjens, "The association between motor subtypes and psychopathology in Parkinson's disease," Parkinsonism Relat. Disord., vol. 15, no. 5, pp. 379-382, Jun. 2009.

[2] M. Selikhova, D. R. Williams, P. A. Kempster, J. L. Holton, T. Revesz, and A. J. Lees, 
“A clinico-pathological study of subtypes in Parkinson's disease," Brain, vol. 132, no. 11, pp. 2947-2957, Nov. 2009.

[3] C. Eggers et al., "Parkinson Subtypes Progress Differently in Clinical Course and Imaging Pattern," PLoS One, vol. 7, no. 10, p. e46813, Oct. 2012.

[4] Noviyanti, Healthy Living Without Gout. Yogyakarta: Notebook, 2015.

[5] M. Darussalam and D. Kartika Rukmi, "Peran Air Rebusan Daun Salam (Syzgium Polyanthum) Dalam Menurunkan Kadar Asam Urat," Media Ilmu Kesehat., vol. 5, no. 2, pp. 83-91, Aug. 2016.

[6] H. Rahman, H. Arifin, G. K. Dewi, and Z. Rizal, "Pengaruh Pemberian Jus Buah Sirsak (Annona Muricata L.)Terhadap Kadar Asam Urat Darah Mencit Putih Jantan Hiperurisemia," in Prosiding Seminar Nasional dan Workshop "Perkembangan Terkini Sains Farmasi dan Klinik IV, ”2014.

[7] S. Dalimartha, Herbal untuk pengobatan reumatik. Jakarta: Penebar Swadaya, 2008.

[8] H. R. Handadari, "Efek Decocta Daun Salam (Eugenia polyantha Wight.) Terhadap Penurunan Kadar Asam Urat dalam Darah Mencit Putih (Mus muculus) Jantan hiperurisemia," Fakultas Farmasi Universitas Muhammadiyah Surakarta, 2007.

[9] Soetarno, Sunardi, and Sudarsono, Estetika pedalangan. Surakarta: Institut Seni Indonesia (ISI) Surakarta dan CV. Adji, 2007.

[10] S. Dalimartha, Atlas tumbuhan obat Indonesia, vol. 2. Jakarta: Niaga Swadaya, 2008.

[11] B. Greenstein and D. F. Wood, At a glance sistem endokrin. Jakarta: Erlangga, 2010.

[12] I. Kusumawati and S. Sugiyanto, "Pengaruh Pemberian Jus Sirsak Terhadap Kadar Asam Urat Pada Penderita Hiperurisemia Di Dusun Semarangan Sidokarto Godean Sleman Yogyakarta." Universitas' Aisyiyah Yogyakarta, 2016.

[13] Handayani, The content of Vitamin C in fruits. Yogyakarta: Pustaka Rihama, 2015. 